\title{
KAJIAN YURIDIS URGENSI AMANDEMEN KELIMA UNDANG-UNDANG DASAR 1945 DALAM SISTEM HUKUM KETATANEGARAAN INDONESIA
}

\author{
Oleh \\ Yoyon M. Darusman \\ Program Pascasarjana Magister Hukum Universitas Pamulang \\ Email: yoyondarusman@yahoo.co.id
}

\begin{abstract}
The concept of state which is based on the rules of law-as stipulated in Chapter I Article 3 of the 1945 Constitution-is the basis of the passage of state and government in Indonesia. The principles stated in this constitution, particularly the ones related to legislative power, should be implemented to control, protect, and evaluate the operation of the state based on the constitution. During the New Order, the 1945 Constitution was untouchable for 32 years; it was most unlikely to amend it. Since the New Order was replaced by the Reform Era and the demand for such amendment grew stronger, the 1945 Constitution has been amended for four times. Yet, this has not been perfectly able to please everyone. Many see that it still has such lack as the issues of parliamentary power: whether to embrace one or two chambers; judicial power: whether to apply centralized or distributed system; and governmental system: whether to implement full or relative presidential system. The above mentioned have resulted in multiinterpretations on the constitution. It therefore leads to a question: is it worth amending the 1945 Constitution for the fifth time?
\end{abstract}

Keywords: State Based on The Rules of Law, Amendment

\begin{abstract}
Abstrak
Konsep Negara hukum adalah prinsip-prinsip yang telah ditetapkan sebagai dasar berjalannya negara dan pemerintah Republik Indonesia, sebagaimana yang telah diatur di dalam Pasal 1 Ayat (3) Undang-Undang Dasar Tahun 1945. Prinsipprinsip yang disebutkan di atas harus dilaksanakan, khususnya yang berhubungan dengan lembaga kekuasaan legislatif dalam rangka mengontrol, melindungi dan mengevaluasi dari pada Undang-Undang Dasar. Pada masa-masa yang lalu khususnya pada masa kurang lebih 32 tahun pemerintahan orde baru telah menjadikan Undang-Undang Dasar 1945 sebagai sesuatu yang tidak dapat disentuh, hal mana Undang-Undang Dasar 1945 tidak dapat diubah atau ditambah. Akan tetapi dengan datangnya era reformasi dan kuatnya tuntutan rakyat, akhirnya Undang-Undang Dasar 1945 telah diubah sampai dengan 4(empat) kali perubahan. Tidak ada sesuatupun yang dilakukan sempurna dan akan memberikan rasa puas kepada semua orang. Hal ini dapat dilihat walaupun Undang-Undang Dasar 1945 telah dilakukan amandemen selama 4(empat) kali masih terjadi berbagai kekurangan diberbagai sektor, khususnya di bidang kekuasaan parlemen dengan sistim dua kamar atau satu kamar, kekuasaan kehakiman dengan sistim kekuasaan terpusat atau terbagi, dan sistim pemerintahan dengan sistim
\end{abstract}


presidensil murni atau relatif. Apa-apa yang disebutkan di atas telah menimbulkan berbagai penafsiran terhadap apa yang dimaksudkan di dalam Undang-Undang Dasar. Karena itu maka lahirlah suatu pertanyaan apakah perlu dilakukan perubahan Undang-Undang Dasar 1945 untuk yang ke 5(lima)?

Kata kunci: negara hukum, perubahan konstitusi

\section{PENDAHULUAN}

Dengan telah dilakukannya amandemen terhadap UUD 1945 maka isi dari Penjelasan UUD 1945 telah ditiadakan, isi serta muatan penjelasannya telah dimasukan ke dalam Batang Tubuh UUD 1945. Kemudian di dalam UndangUndang Dasar 1945 Pasal 1 ayat 3 pasca amandemen ke ketiga mengatur bahwa Negara Indonesia adalah negara hukum. Artinya didalam interaksi berbangsa dan bernegara senantiasa didasarkan kepada aruran-aturan hukum yang telah disepakati bersama oleh rakyat yang ada di dalam negara Indonesia.

Penegasan tentang negara hukum di dalam Undang-Undang Dasar 1945 sebelum amandemen terdapat di dalam Penjelasan Undang-Undang Dasar 1945 dan tidak dicantumkan di dalam Batang Tubuh Undang-Undang Dasar $1945 .{ }^{1} \mathrm{Hal}$ ini di dalam praktek ketatanegaraan dapat menimbulkan berbagai pemahaman (multi tafsir) terhadap isi Undang-Undang Dasar 1945.

Oleh karena itu, pada saat terjadinya amandemen dan untuk menghindari terjadinya berbagai pemahaman (multi tafsir), maka Majelis Permusyawaratan Rakyat (MPR) saat itu berupaya untuk memasukkan istilah negara hukum yang tadinya di dalam Penjelasan Undang-Undang Dasar 1945 ke dalam Batang Tubuh Undang-Undang Dasar 1945.

Dalam sejarah konstitusi Republik Indonesia, konstitusi telah mengalami perubahan maupun penggantian yang dilakukan oleh pemerintahan masa lalu sampai masa kini dengan berbagai pertimbangan kondisi sosial, politik maupun ekonomi yang sangat sulit untuk dihindarkan.

\footnotetext{
${ }^{1}$ PenjelasanUUD 1945 (sebelum amandemen).Sistem pemerintahan negara ialah ; Indonesia negara yang berdasarkan atas hukum (rechtstaat).Negara Indonesia berdasar atas hukum (rechtstaat), tidak berdasarkan kekuasaan belaka (Machtsstaat).
} 
Sejak ditetapkan oleh Panitia Persiapan Kemerdekaan Indonesia (PPKI) pada tanggal 18 Agustus 1945, Undang-Undang Dasar 1945 karena berbagai situasi dan kondisi politik saat itu belum dapat berjalan efektik sebagaimana yang diinginkan, yang akhirnya karena tekanan politik kolonial Belanda dalam konfrensi meja bundar (KMB) di Den Haag (23/08/1949) yang pada akhirnya tanggal 27 Desember 1949, maka digantilah UUD 1945 dengan Konstitusi Republik Indonesia Serikat (KRIS). ${ }^{2}$ Hal ini disebabkan keberadaan pemerintahaan saat itu masih belum memiliki pengakuan internasional (dejure) sehingga secara kewilayahan pemerintahan Indonesia masih bergerilya dan berpindah-pindah.

Perjalanan sistem pemerintahan Indonesia dalam kerangka Konstitusi Republik Iindonesia Serikat (KRIS) dengan sistem federasi ternyata di dalam perjalannya tidaklah berjalan mulus, pergolakan rakyat untuk menolak sistem federasi yang ingin kembali kepada negara kesatuan sangatlah kuat. Memperhatikan keadaan tersebut akhirnya Kabinet RIS mengundangkan Undangundang Darurat Nomor: 10 Tahun 1950 yang mengatur penyerahan tugas-tugas pemerintahan di Jawa Timur kepada Komisaris Pemerintah.

Pada akhirnya keputusan tersebut diikuti seluruh pemerintahan di wilayah Indonesia, dan kemudian ditetapkanlah Undang-Undang Dasar Sementara (UUDS) 1950 menggantikan Konstitusi RIS. ${ }^{3}$ Hal tersebut sudah sewajarnya terjadi karena memang perubahan konstitusi dari UUD 1945 dengan konsep negara kesatuan menjadi KRIS dengan konsep federasi adalah suatu keinginan yang dipaksakan oleh pemerintah belanda bukan keinginan rakyat Indonesia.

Gejolah politik pasca pemberlakuan UUUDS 1950 ternyata belumlah berjalan kondusif, hal ini ditandai perselisihan dalam rangka pelaksanaan pelaksanaan pemilu tahun 1955. Terjadi beberapa pergolakan di dalam negeri antara lain Republik Maluku Selatan (RMS). Darul Islam/Tentara Islam Indonesia (DI/TII) pimpinan Karto Suwiryo di Jawa Barat, Kahar Muzakar di Sulawesi,

\footnotetext{
${ }^{2}$ Dasril Radjab, Hukum Tata Negara Indonesia, (Jakarta: Rineka Cipta, 2005), hal.193.

${ }^{3}$ Ibid.
} 
Tengku Daud Beureuh di Aceh, dan Ibnu Hajar di Kalimantan. Pemilu tahun 1955 untuk memilih anggota DPR dan anggota Kontituante tetap dapat dilaksanakan dengan baik. Pemilu tahun 1955 ini tercatat sebagai Pemilu pertama yang demokratis dalam sejarah Indonesia.

Disamping itu, konflik kepemimpinan di kalangan elit politik tidak dapat diselesaikan dengan baik, bahkan Wakil Presiden Mohamad Hatta mengundurkan diri pada tanggal 1 Desember 1956. Yang pada akhirnya Presiden Soekarno mengeluarkan Dekrit tanggal 5 Juli 1959 yang salah satunya isinya adalah menyatakan kembali kepada UUD $1945 .^{4}$

Pada era orde baru yang telah hampir 32 tahun pemerintahan Presiden Soeharto mensakralkan UUD 1945, sehingga jedah waktu itu tidak terjadi perubahan. Dengan ditandai dengan gejolak politik pada tahun 1998 dan bergeloranya semangat reformasi, pada akhirnya UUD 1945 yang disakralkan itu dalam kenyataannya sampai saat ini telah dilakukan amandemen yang ke empat kalinya dan semuanya berjalan dengan aman dan terkendali. Namun demikian dalam pelaksanaanya, terdapat hal-hal yang sudah sempurna maupun hal-hal yang belum sempurna pasca amandemen yang ke empat ini dalam sistem ketatanegaraan Indonesia.,

Hal ini menunjukan bahwa bagaimana pentingnya kontitusi sebagai hukum dasar harus senantiasa mampu memberikan perlindungan serta harapan yang terbaik kepada masyarakat. Karena itu untuk memenuhi harapan rakyat dan masyarakat tersebut kiranya layak dipertanyakan apakah masih diperlukan amandemen UUD 1945 yang ke lima dan seterusnya?

\section{PEMBAHASAN}

\section{Konsep Negara Hukum}

Kalau kita lihat pendapat para sarjana hukum, maka konsep adat-istiadat yang bukan milik orang yang tak mampu. Negara-hukum yang berkembang di negara-negara Eropah Kontinental yang menjelaskan di mana dapat dirangkum 
dari : (1) Immanuel Kant dengan Rechts Staats, ${ }^{5}$ yaitu suatu konsep keberadaan suatu negara dilandaskan kepada adanya aturan hukum bukan didasarkan kepada kekuasaan, sedangkan (2) A.V. Decey dengan The Rule of Law, ${ }^{6}$ yaitu suatu konsep yang berkembang di negara-negara Anglo Saxon yang menjelaskan bahwa bahwa kekuasaan yang tertinggi di dalam negara adalah hukum, tiada satupun yang memiliki kekuasaan melebihi hukum.

Dengan memiliki ciri-ciri $:^{7}$ 1) the supremacy of law yakni hukum sebagai panglima 2) the equality before the law yakni kesetaraan dimuka hukum dan 3) the due procees of law yakni penerapan hukum sesuai ketentuan hukum yang sudah ada.

Hans Kelsen menjelaskan ciri-ciri "Rechtstaat" yaitu ${ }^{8}:$ 1) negara berkehidupannya sejalan dengan konstitusi dan undang-undang yang dibuat oleh parlemen 2) negara mengatur pertanggunganjawab atas setiap kebijakan dan tindakan yang telah dilakukan oleh negara 3) negara menjamin adanya kekuasaan kehakiman dan 4)negara melindungi hak azasi manusia.

\section{Konstitusi}

Pengertian konstitusi dapat dirujuk kepada pendapat para sarjana hukum khususnya di bidang hukum tata negara. Pengertian konstitusi dapat dirangkum dari pendapat : (1) Jimlly Assidiqy bahwa norma dasar atau dapat disebut juga dengan hukum dasar adalah merupakan aturan hukum yang tertinggi yang tidak dapat dikesampingkan begitu saja tanpa ada suatu proses hukum yang

\footnotetext{
${ }^{5}$ www.wikipedia.com. 06/01/2014. Rechtstaat (German: Reechstaat) is a concept in continental European legal thinking, originally borrowed from German jurisprudence, which can be translated as "legal state", "state of law", "state of justice", or "state of rights". It is a "constitutional state" in with the exercise of governmental power is contrained by the law, and is often tied to the Anglo-American concept of the rule of law. (Rechstaat adalah merupakan konsep pemikiran hukum Eropah Kontinental, yang aslinya diambil dari jurisprudensi German, yang dapat diterjemahkan sebagai"negara hukum", "keadilan negara", atau "hak-hak negara", merupakan "konstitusi negara" yang dilakukan pada kekuasaan negara yang berkaitan dengan hukum, dan sering digunakan terhadap konsep aturan hukum Anglo Amerika).

${ }^{6}$ Ibid.

${ }^{7}$ Ibid. 198.

${ }^{8}$ Ni'matul Huda, Hukum Tata Negara Indonesia, (Jakarta: Raja Grafindo Persada, 2005), hal.
} 
memberikan ruang untuk dapat mengenyampingkan hukum dasar tersebut. Hukum dasar di dalam praktek ketatanegaraan di dunia pada umumnya dapat dibagi menjadi 2(dua) pengertian yaitu; hukum dasar yang tertulis (written law) dan hukum dasar yang tidak tertulis (unwritten law). ${ }^{9}$ Hukum Dasar, adalah suatu norma/kaidah/aturan hukum yang tertinggi di dalam suatu negara baik yang tertulis maupun yang tidak tertulis, yang dijadikan sebagai sumber dari segala sumber hukum berbangsa dan bernegara. ${ }^{10}$

Lalu bagaimana dengan pengertian Undang-Undang Dasar: Jimly Asshidiqy menjelaskan bahwa: Undang-undang Dasar adalah merupakan hukum dasar yang tertulis, yang dijadikan sebagai sumber hukum yang tertinggi didalam berbangsa dan bernegara.

(Konstitusi) juga merupakan aturan dasar (Political Contract) berbangsa dan bernegara yang dibuat secara tertulis oleh lembaga pembuat undang-undang (parliemant istitution) sebagai acuan tata laksana peraturan hukum dan perundang-undangan, didalam suatu negara. Konstitusi dapat diartikan sebagai hukum dasar karena merupakan hukum dasar yang tertulis maupun tidak tertulis, yang dijadikan sebagai sumber hukum yang tertinggi didalam berbangsa dan bernegara. $^{11}$

Dalam kamus Oxford Dictionary of Law, perkataan constitution diartikan juga sebagai ; "the rules and practices that determine the composition and functions of the organs of the central and local government in a state and regulate the relationship between individual and the state". ${ }^{2}$ Yaitu bahwa Konstitusi adalah merupakan aturan-aturan dan praktek-praktek yang menentukan komposisi dan fungsi dari organ-organ atau bagian-bagian yang ada di dalam pemerintahan

\footnotetext{
${ }^{9}$ Jimly Asshidiqy (a), Menuju Negara Hukum Yang Demokratis, (Jakarta: Sekeretariat Jenderal Makamah Konstitusi RI, 2008), hal. 135.

${ }^{10}$ Ibid.

${ }^{11}$ Ibid.

${ }^{12}$ Jimly Asshidiqy (b), Pengantar Ilmu Hukum Tata Negara, (Jakarta: Raja Grafindo Persada ,2009), hlm. 95.
} 
pusat dan daerah pada negara, yang mengatur pula hubungan antara warga negara atau perorangan dengan negara.

Di dalam referensi hukum tata negara karakteristik (sifat) dari konstitusi dapat di bagi ke dalam dua bagian yaitu: 1) Konstitusi yang bersifat flaxible (lentur) artinya konstitusi secara formil maupun secara materil dapat diubah dan atau ditambah bahkan dapat disesuaikan dengan kebutuhan dan perkembangan zaman; dan 2) Konstitusi yang rigid (kaku) artinya konstitusi secara formil maupun secara materil tidak dapat diubah dan atau ditambah.

Bahkan sangat sulit untuk dapat disesuaikan dengan kebutuhan dan perkembangan masyarakat. ${ }^{13}$. Konstitusi yang fleksibel dapat dilihat dari konstitusi yang dalam batang tubuhnya telah memberikan suatu aturan khusus bagaimana cara perubahan konstitusi.

Misalnya dalam UUD 1945 pasal 37 mengatur tentang tata cara perubahan UUD. Sedangkan konstitusi yang rigid dapat dilihat dari konstitusi yang dalam batang tubuhnya tidak memberikan suatu aturan khusus bagaimana cara perubahan konstitusi tersebut. Hal ini dapat dilihat misalnya dalam konstitusi Amerika Serikat.

\section{Amandemen dan Kelembagaan Yang Terkait.}

\section{a. Amandemen.}

Pengertian amandemen secara tata bahasa berasal dari bahasa Inggris yaitu "amends" yang artinya "rubah", yang kalau dijadikan kata kerja adalah "amendment" yang artinya "merubah". ${ }^{14}$ Amandemen dalam pengertian hukum ketatanegaraan dapat diartikan sebagai: mengubah, atau menambah atau bahkan menghapus ketentuan di dalam ketentuan hukum dan perundang-undangan ${ }^{15}$. Dalam pengertian konstitusional naskah asli Undang-Undang Dasar 1945 dalam

\footnotetext{
${ }^{13}$ Muhammad Kusnardi dan Harmaily Ibrahim, Pengantar Hukum Tata Negara Indonesia. (Jakarta: Pusat Studi Hukum Tata Negara Indonesia, 1983), hal. 53

${ }^{14}$ John M. Echols, Hassan Sadily, Kamus Iggris Indonesia: An-English-Indonesian Dictionary, (Jakarta: Gramedia, 2005), hal. 26.

${ }^{15}$ Muhammad Kusnardi dan Harmaily Ibrahim, Op. Cit., hal.
} 
pasal 37 ayat (1) dijelaskan bahwa "untuk mengubah Undang-Undang Dasar sekurang-kurangnya 2/3 daripada jumlah anggota Majlis Permusyawaratan Rakyat harus hadir". ${ }^{16}$

Dalam kaitan dengan amandemen itu, MPR sendiri secara resmi menggunaan istilah "perubahan", namun demikian di dalam pengertian ketatanegaraan istilah "perubahan" maupun "amandemen" dapat dipergunakan secara bergantian dalam pengertian yang sama. Selain karena alasan bahwa istilah amandemen lebih popular dan banyak di gunakan di tengah-tengah masyarakat, penggunaan istilah ini secara ilmu konstitusi dan ketatanegaraan juga tidak salah, istilah amandemen memang juga berarti perubahan. ${ }^{17}$

Franscois Venter berpendapat konsep "konstitusi" itu dinamis. Menurutnya, konstitusi yang "final" itu tidak ada karena konstitusi suatu negara itu bergerak bersama-sama dengan negara itu sendiri. ${ }^{18}$ Sedangkan John P. Wheeler, Jr, terang-terangan berpendapat bahwa perubahan konstitusi adalah suatu keniscayaan. ${ }^{19}$ Di sisi lain Romano Prodi bahkan mengatakan "konstitusi yang tidak bisa diubah adalah konstitusi yang lemah" karena itu "ia tidak bisa beradaptasi dengan realitas, padahal konstitusi harus bisa diadaptasikan dengan realitas yang terus berubah. ${ }^{20}$ Pada dasarnya Undang-Undang Dasar 1945 adalah merupakan konstitusi yang lentur (flexible) hal ini dikarenakan dalam ketentuan pasal 37 Undang-Undang Dasar 1945 naskah asli sebelum perubahan, maupun naskah sesudah perubahan tetap mengatur tentang tata cara bagaimana merubah

\footnotetext{
${ }^{16}$ Perubahan Undang-Undang Dasar 1945 sebelum era reformasi adalah merupakan suatu hal yang sangat sulit untuk dilakukan, selain karena memang tidak ada keinginan (goodwill) dari penguasa juga diciptakan suatu paradigma bahwa Undang-Undang Dasar 1945 adalah merupakan suatu karya yang agung yang tidak pantas untuk dilakukan perubahan. Pada era reformasi dan bergeloranya tuntutan reformasi yang salah satu dari tuntutan itu adalah segera dilakukannya perubahan Undang-Undang Dasar 1945, yang pada akhirnya telah dilakukan perubahan UndangUndang Dasar 1945.

${ }^{17}$ Moh. Mahfud MD., Perdebatan Hukum Tata Negara Pasca Amandemen Konstitusi, (Jakarta: LP3ES 2007), hal. xi.

${ }^{18}$ Lihat Naskah Akademik Perubahan Kelima Undang-Undang Dasar Negara Republik Indonesia Tahun 1945, Kelompok DPD Di MPR RI. Jakarta 2011, hal. 1.

${ }^{19}$ Ibid.

${ }^{20}$ Ibid.
} 
Undang-Undang Dasar 1945. Hal ini dapat dilihat dalam ketentuan di bawah ini: Pasal 37 Undang-Undang Dasar 1945 naskah asli. Ayat (1) Untuk mengubah Undang-Undang Dasar sekurang-kurangnya 2/3 daripada jumlah anggota Majlis Permusyawaratan Rakyat harus hadir. Ayat (2) Putusan diambil dengan persetujuan sekurang-kurangnya 2/3 daripada jumlah anggota yang hadir.

Pasal 37 Undang-Undang Dasar 1945 naskah perubahan. Dalam ayat (1) dijelaskan usul perubahan pasal-pasal Undang-Undang Dasar yang diagendakan dalam sidang Majelis Permusyawaratan Rakyat, dan diajukan oleh sekurangkurangnya 1/3 dari jumlah anggota Majelis Permusyawaratan Rakyat. Ayat (2) setiap usul perubahan pasal-pasal Undang-Undang Dasar diajukan secara tertulis dan ditunjukan dengan jelas bagian yang diusulkan untuk diubah beserta alasannya. Ayat (3) Untuk mengubah pasal-pasal Undang-Undang Dasar sidang Majelis Permusyawaratan Rakyat dihadiri oleh sekurang-kurangnya 2/3 dari jumlah anggota Majelis Permusyawaratan Rakyat. Ayat (4) Putusan untuk mengubah pasal-pasal Undang-Undang Dasar dilakukan dengan persetujuan sekurang-kurangnya lima puluh persen ditambah satu anggota dari seluruh anggota Majelis Permusyawaratan Rakyat. Ayat (5) Khusus mengenai bentuk Negara Kesatuan Republik Indonesia tidak dapat dilakukan perubahan.

Dengan memperhatikan ketentuan yang mengatur tentang tata cara perubahan Undang-Undang Dasar 1945 sebagaimana yang diatur di dalam Pasal 37 dalam naskah asli maupun dalam naskah perubahan, secara normatif UndangUndang Dasar 1945 adalah merupakan konstitusi yang masih memiliki sifat lentur (flexible) hal ini disebabkan didalam batang tubuhnya masih mengatur bagaimana tata cara mengubah Undang-Undang Dasar tersebut. Akan tetapi di sisi lain jika dilihat secara empiris dengan melihat ketentuan Undang-Undang Dasar 1945 yang disebutkan dalam Pasal 37 Ayat (1) dan (2) naskah asli dan Pasal 37 Ayat (1),(2),(3),(4) dan (5) naskah perubahan, Undang-Undang Dasar 1945 adalah merupakan konstitusi yang memiliki sifat kaku (rigid). Hal ini dapat dilihat secara empiris bahwa Majelis Permusyawaratan Rakyat sebagai lembaga parlemen yang memiliki kewenangan untuk mengubah Undang-Undang Dasar 1945 di dalamnya terdiri kekuatan-kekuatan politik yang sangat sulit untuk dihitung dengan angka 
pada saat adanya keinginan-keinginan untuk melakukan perubahan UndangUndang Dasar 1945. Secara empiris telah dilihat sejak era kepemimpinan MPR Hidayat Nurwahid maupun era saat ini yaitu kepemimpinan Alm. Taufik Kemas belum melakukan perubahan Undang-Undang Dasar 1945 sesuai dengan harapan masyarakat.

Hal lain sebagai suatu perbandingan sebaliknya berbeda dengan tata cara perubahan yang dilakukan di dalam Konstitusi Amerika Serikat. Secara normatif Konstitusi Amerika Serikat memiliki sifat kaku (rigid) hal ini dapat dilihat seluruh pasal-pasal (sections) maupun ayat-ayat (article) dari pasal I sampai dengan pasal VIII tidak mengatur secara tegas tentang bagaimana cara melakukan perubahan Konstitusi Amerika Serikat. Akan tetapi jika dilihat dari sisi empiris Konstitusi Amerika Serikat dapat dikatakan memiliki sifat lentur (flexible) hal ini dikarenakan sejak ditetapkan pada tanggal 17 September 1987 sampai saat ini Konstitusi Amerika Serikat telah dilakukan lebih dari 28 kali perubahan. Ini artinya bahwa Konstitusi Amerika Serikat bukan merupakan sesuatu yang disakralkan akan tetapi senantiasa disesuaikan dengan perkembangan dan keinginan rakyat Amerika Serikat. Walaupun proses dan tata cara perubahannya tidak sama seperti yang diatur dalam Undang-Undang Dasar 1945.

\section{b. Sistem Lembaga Parlemen (Parliament System).}

Pengertian parlemen adalah diambil dari bahasa Inggris yaitu "parliament". "Parliament" secara tata bahasa (etimologi) berasal dari bahasa Inggris yaitu "parley" yang artinya perembukan atau permusyawaratan, dalam kata benda disebut "parliament" yaitu lembaga parlemen atau dewan perwakilan rakyat. Lembaga parlemen di dalam praktek ketatanegaraan secara umum sebagai lembaga yang memiliki kekuasaan pada cabang legislatif yaitu kekuasaan yang memiliki kewenangan untuk membentuk perundang-undangan.

Di dalam praktek ketatanegaraan diberbagai negara saat ini sistem parlemen atau sistem parlementariat yang dibentuk dengan sistem "satu kamar" 
(unicameral system) dan sistem "dua kamar" (bicameral system). ${ }^{21}$ Sistem satu kamar adalah lembaga parlemen yang semua kewenangannya tersentral hanya pada satu kamar (chamber) saja tidak ada pembagian kepada kamar (chamber) yang lain. Hal ini biasanya dilakukan pada negara-negara kesatuan yang memiliki wilayah sangat kecil dan menganggap keberadaan majelis tinggi sangatlah tidak effisien, seperti negara Denmark dan Selandia Baru. ${ }^{22}$ Selain itu juga terdapat beberapa negara besar yang menganut sistem parlemen satu kamar (unicameral), terutama negara-negara yang sampai saat ini masih menerapkan sistem sosialisme/komunisme murni, seperti RRC.

Sedangkan sistem dua kamar adalah lembaga parlemen yang membagi menjadi dua kamar (chambers) atau lebih. Pada prakteknya hanya ada dua kamar saja yaitu satu kamar dipegang oleh Majlis Tinggi (House of Lords) dan kamar yang lain dipegang oleh Majelis Rendah (House of Commons atau Representatif). Misalnya di Inggris Majlis Tinggi dipegang oleh House of Lords sebagai perwakilan kekuasaan kerajaan sedang Majelis Rendah dipegang oleh House of Commons sebagai perwakilan kekuasaan pemerintahan di Parlemen. Begitu juga jika melihat sistem parlemen dalam praktek ketatanegaraan Amerika Serikat, juga menganut sistem parlemen dengan dua kamar (becameral system), di mana lembaga parlemen Amerika Serikat di pegang oleh Kongres Amerika Serikat (the Congress of United States of America) yang di dalamnya terdiri dari Senat (Senate) yaitu merupakan lembaga parlemen yang mewakili negara-negara bagian dan Dewan Perwakilan Rakyat (House of Representative) yaitu lembaga parlemen yang mewakili partai politik. Hal tersebut dapat dilihat dalam ketentuan Konstitusi Amerika Serikat Pasal 1 Ayat 1 sebagai berikut : Pasal 1 Ayat 1 Undang-Undang Dasar Amerika Serikat menjelaskan bahwa "Semua kekuasaan legislatif yang ditetapkan di sini akan diberikan kepada sebuah Kongres Amerika Serikat, yang terdiri dari sebuah Senat dan Dewan Perwakilan Rakyat”.

\footnotetext{
${ }^{21}$ Jimly Assidiqy, Op. Cit.

${ }^{22}$ Www.wikipedia.com 07/01/2014.
} 
Pada sisi lain pelaksanaan sistem dua kamar (becameral system) khususnya dalam praktek ketatanegaraan Indonesia pasca amandemen UndangUndang Dasar 1945 terutama jika dilihat dari kewenangan masing-masing lembaga parlemen tersebut, baik DPR maupun DPD memiliki kewenangan yang berbeda, artinya antara DPR dan DPD tidak memiliki kekuatan yang sama. Hal tersebut berarti bahwa sistem parlemen Indonesia menganut sistem dua kamar yang lemah (soft becameral system) dan bukan sistem dua kamar yang kuat (strong becameral system). Hal ini dapat dilihat dalam ketentuan Undang-Undang Dasar 1945 naskah perubahan sebagai berikut : Pasal 20 Ayat 1 Undang-Undang Dasar 1945 naskah perubahan menjelaskan bahwa "Dewan Perwakilan Rakyat memegang kekuasaan membentuk undang-undang”. Pasal 22D Ayat 1 UndangUndang Dasar 1945 naskah perubahan menjelaskan bahwa "Dewan Perwakilan Daerah dapat mengajukan kepada Dewan Perwakilan Rakyat rancangan undangundang yang berkaitan dengan otonomi daerah, hubungan pusat dan daerah, pembentukan dan pemekaran serta penggabungan daerah, pengelolaan sumber daya alam dan sumber daya ekonomi lainnya, serta yang berkaitan dengan perimbangan keuangan pusat dan daerah".

Sistem parlemen Indonesia dikatakan menganut sistem parlemen dua kamar yang lemah (soft becameral system) dapat dilihat dari ketentuan pasal 20 Ayat 1 UUD 1945 yang menegaskan bahwa "DPR memegang kekuasaan membentuk Undang-Undang”, sementara jika melihat ketentuan pasal 22 D Ayat 1 UUD 1945 yang menegaskan bahwa "DPD dapat mengajukan kepada DPR rancangan undang-undang........, disini sudah jelas tampak dua lembaga negara yang kewenangannya sangat berbeda jauh, disatu sisi DPR sangat kuat memiliki kekuasaan membentuk UU sementara DPD hanya memiliki kewenangan untuk mengusulkan rancangan UU.

Hal tersebut tentunya sangat berbeda dengan sistem parlemen Amerika Serikat yang menganut sistem dua kamar yang kuat (strong becameral system). Seperti yang ditegaskan dalam konstitusi Amerika Serikat Pasal 1 Ayat 1. "Semua kekuasaan legislatif yang ditetapkan di sini akan diberikan kepada sebuah Kongres Amerika Serikat, yang akan terdiri dari sebuah Senat dan Dewan 
Perwakilan Rakyat". Pengertian "kekuasaan" disini adalah semua hal-hal yang berkaitan dengan pembentukan perundang-undangan di dalam kongres dilakukan secara bersama-sama antara Senat dan DPR. ${ }^{23}$

Artinya antara Senat dan DPR memiliki kekuasaan dan kewenangan yang sama dalam hal pembentukan perundang-undangan Amerika Serikat. Di Amerika Serikat Majelis Tinggi dipegang oleh Senat sebagai perwakilan kekuasaan dari negara-negara bagian dan Majelis Rendah dipegang oleh House of Representatif (DPR) sebagai perwakilan kekuasaan dari partai politik.

\section{c. Sistem Lembaga Peradilan (Judiciary System).}

"Judiciary" secara tata bahasa (etimologi) berasal dari bahasa Inggris yaitu "judicial" yang artinya pengadilan atau mengadili, dalam kata benda disebut “judiciary" yang artinya lembaga peradilan atau kekuasaan kehakiman. ${ }^{24}$ Dalam bahasa Indonesia, fungsi kekuasaan kehakiman seringkali disebut cabang kekuasaan "yudikatif", mengambil istilah dari bahasa belanda "judicatief". Lembaga yudikatif di dalam sistem ketatanegaraan Republik Indonesia adalah menganut sistem lembaga yudikatif dengan dengan sistem terbagi-bagi (distribution) yang mana didalam lembaga yudikatif terdapat beberapa lembaga yang di dalamnya memiliki kewenangan sendiri-sendiri.

Jimly Assidiqy menjelaskan dalam sistem negara modern, cabang kekuasaan kehakiman atau "judiciary "merupakan cabang yang diorganisasikan secara tersendiri. Oleh karena itu dikatakan oleh John Alder, "The principle of sparation of power is particulary important for the judiciary". Bahkan, boleh jadi, karena Montesquieu adalah seorang hakim Perancis. Dalam bukunya ' $L$ 'Esprit des Lois" ia mengimpikan pentingnya pemisahan kekuasaan yang ekstrim antara cabang kekuasaan legislative, eksekutif dan terutama kekuasaan yudukatif'. ${ }^{25}$

\footnotetext{
${ }^{23}$ Muhammad Kusnardi dan Harmaily Ibrahim, Op. Cit., hal. 53.

${ }^{24}$ John M. Echols, Et.al, Op. Cit., hal.

${ }^{25}$ Jimly Assidiqy (b), Op. Cit., hal. 310.
} 
Di dalam praktek ketatanegaraan khususnya di bidang kekuasaan kehakiman secara umum lembaga peradilan yang kekuasaannya dipusatkan di dalam suatu lembaga peradilan (sentralistik) seperti yang dilakukan oleh Mahkamah Agung Amerika Serikat (Sumpreme Court of United State) sebagai pemegang kekuasaan tunggal. Mahkamah Agung Amerika Serikat di dalamnya memiliki kewenangan di bidang peradilan umum, peradilan konstitusi maupun pengawasan internal lembaga peradilan. Walaupun secara vertikal kelembagaan peradilan memiliki cabang-cabang di negara-negara bagian maupun di distrikdistrik. Akan tetapi secara otoritas memiliki kewenangan yang sama.

Namun demikian di sisi lain terdapat praktek-praktek ketatanegaraan yang secara khusus lembaga peradilan yang kekuasaannya didistribusikan (menurut UUD) kepada lembaga-lembaga lain (distributif). Artinya pemegang kekuasaan lembaga kehakiman tidak hanya dipegang oleh Mahkamah Agung (Supreme Court) tetapi juga dipegang oleh lembaga kehakiman lain. Hal ini dapat dilihat dalam lembaga kehakiman Republik Federal German terdiri "Supreme Court" dan "Constitutional Court", kemudian lembaga kehakiman Republik Perancis memiliki "Supreme Court" dan "Constitutional Court". Dan lembaga kekuasaan kehakiman Republik Indonesia, termasuk yang membagi kekuasaan kehakiman yang ditandai dengan adanya Mahkamah Agung (MA) untuk peradilan umum, Mahkamah Konstitusi (MK) ${ }^{26}$ untuk peradilan umum dan Komisi Yudisial $(\mathrm{KY})$ sebagai lembaga pengawasan internal pada lembaga peradilan. $^{27}$

\footnotetext{
${ }^{26}$ Pasal 24 C Undang-Undang Dasar 1945 naskah perubahan. Ayat (1) Mahkamah Konstitusi berwewenang mengadili pada tingkat pertama dan terakhir yang putusannya bersifat final untuk menguji undang-undang terhadap Undang-undang Dasar, memutus sengketa kewenangankewenangan lembaga Negara yang kewenangannya diberikan oleh Undang-undang Dasar, memutus pembubaran partai politik, dan memutus perselisihan tentang pemilihan umum. Pasal 24 B Undang-Undang Dasar 1945 naskah perubahan. Ayat (1) Komisi Yudisial bersifat mandiri yang berwewenang mengusulkan pengangkatan hakim agung dan mempunyai wewenang lain dalam rangka menjaga dan menegakan kehormatan, keluhuran martabat, serta perilaku hakim.

${ }^{27}$ Lembaga yudikatif Indonesia dipegang oleh lembaga negara yang namanya Mahkamah Agung, Mahkamah Konstitusi dan Komisi Yudisial, diatur dalam ketentuan UUD 1945, yaitu sebagai berikut : Pasal 24 Undang-Undang Dasar 1945 naskah perubahan menjelaskan :Ayat (1) Kekuasaan kehakiman merupakan kekuasaan yang merdeka untuk menyelenggarakan peradilan guna menegakan hukum dan keadilan. Ayat (2) Kekuasaan kehakiman dilakukan oleh sebuah Mahkamah Agung dan badan peradilan yang berada dibawahnya dalam lingkungan peradilan umum, lingkungan peradilan agama, lingkungan peradilan militer, lingkungan peradilan tata usaha
} 


\section{d. Sistem Pemerintahan (Government System).}

M. Mahfud M.D, menjelaskan di dalam referensi hukum tata negara dikenal tiga sistem pemerintahan, ${ }^{28}$ yaitu : 1) sistem pemerintahan parlementer seperti di Inggris, 2) sistem pemerintahan presidensial seperti di Amerika Serikat dan 3) sistem pemerintahan referendum seperti di Swis. Sistem pemerintahan parlementer adalah suatu pemerintahan yang kedudukan parlemen memiliki kedudukan yang lebih kuat, yang ditandai dengan $:^{29}$

a. Kepala Negara (Presiden atau Raja/Ratu) tidak berkedudukan sebagai kepala pemerintahan, karena ia hanya simbol (pemersatu bangsa).

b. Kepala Negara tidak dapat diminta pertanggungjawaban atas pelanggaran pemerintahan (the King can do not wrong).

c. Kekuasaan pemerintahan secara riel dipegang oleh Perdana Menteri yang memimpin sebuah Kabinet.

d. Kabinet baik secara bersama-sama maupun perseorangan bertanggung jawab kepada Parlemen (DPR), dan Kabinet dapat dijatuhkan oleh Parlemen (DPR), dengan alasan tidak repsentatif lagi.

Sistem pemerintahan presidensial adalah suatu pemerintahan yang kedudukan parlemen tidak memiliki kedudukan yang lebih kuat akan tetapi sama (balance), yang ditandai dengan $:^{30}$

a. Presiden disamping sebagai Kepala Negara juga Kepala Pemerintahan.

b. Presiden memegang kekuasaan eksekutif secara riel.

c. Presiden tidak bertanggung jawab kepada Parlemen (DPR);

d. Presiden dibantu oleh menter-menteri yang diangkat dan diberhentikan oleh Presiden.

negara, dan oleh sebuah Mahkamah Konstitsi. Ayat (3) Badan-badan lain yang fungsinya berkaitan dengan kekuasaan kehakiman diatur dalam undang-undang.

${ }^{28}$ I Dewa Made Atmadja, Hukum Konstitusi, Problematika Konstitusi Indonesia Sesudah Perubahan UUD 1945, (Malang: Setia Press, 2012), hal. 180.

$$
\begin{aligned}
& { }^{29} \text { Ibid } \\
& { }^{30} \text { Ibid }
\end{aligned}
$$


e. Eksekutif dan legislatif kedudukannya sejajar dan sama-sama kuat. Presiden tidak dapat dijatuhkan oleh Parlemen (DPR) dan sebaliknya Parlemen (DPR) tidak dapat menjatuhkan Presiden,

Sistem pemerintahan referendum adalah suatu pemerintahan yang proses pembentukan hukum dan perundang-undangan ditentukan oleh hasil referendum (jajak pendapat) secara langsung, yang ditandai dengan $:{ }^{31}$

a. Referendum obligator, yakni setiap peraturan atau Undang-Undang yang dibuat legislative bersama-sama eksekutif wajib mendapat persetujuan dari rakyat, disebut referendum wajib.

b. Referendum fakultatif, yakni peraturan atau Undang-Undang yang ada terus diberlakukan atau harus dicabut, disebut referendum tidak wajib.

Namun demikian di dalam praktek ketatanegaraan di dunia termasuk di Indonesia terdapat sistem pemerintahan yang di dalamnya memiliki ciri-ciri atau unsur-unsur dari sistem parlementer maupun sistem presidensil, atau sistem campuran (mix system) di mana suatu sistem pemerintahan yang di dalam konstitusinya mengatur keterpaduan antara sistem parlementer maupun sistem presidensil. Hal tersebut tentunya merupakan bahan kajian para ahli hukum agar perkembangan sistem hukum tersebut baik atau kurang baik.

Kekuasaan pemerintahan dalam sistem ketatanegaraan Indonesia telah bergeser secara besar-besaran dari suatu sistem parlementer di mana pemegang kekuasaan pemerintahan dalam hal ini Presiden yang selama ini selaku mandataris MPR karena diangkat dan diberhentikan oleh MPR, telah bergeser kearah suatu sistem presidensil di mana pemegang kekuasaan pemerintahan dalam hal ini presiden tidak bertanggung jawab kepada MPR karena tidak diangkat dan diberhentikan oleh MPR, melainkan bertanggung jawab kepada rakyat, karena Presiden dipilih secara langsung oleh rakyat.

Hal ini dapat dilihat dalam ketentuan Undang-Undang Dasar 1945, sebagai berikut : Pasal 4 Undang-Undang Dasar 1945 naskah perubahan. Ayat (1) Presiden Republik Indonesia memegang kekuasaan pemerintahan menurut 
Undang-Undang Dasar. Ayat (2) Dalam melakukan kewajibannya Presiden dibantu oleh satu orang Wakil Presiden. Pasal 6A Ayat 1) Presiden dan Wakil Presiden dipilih dalam satu pasangan secara langsung oleh rakyat.

Dengan memperhatikan ketentuan tersebut, pada dasarnya dapat dikatakan menganut sistem pemerintahan presidensil, hal ini dikarenakan prinsipprinsip yang dianut dalam sistem pemerintahan presidensil sebagian telah diakomodir dalam ketentuan UUD 1945, seperti ; 1) Presiden tidak bertanggung jawab kepada parlemen; 2) Masa jabatan pemerintahan telah ditetapkan; 3) Pemilihan Presiden tidak dilakukan oleh Parlemen tetapi langsung oleh rakyat; 4) Parlemen dan Presiden tidak saling menjatuhkan. Akan tetapi dalam sisi-sisi lain pelaksanaannya dapat saja terdapat kekurangan-kekurangan, misalnya ; pelaksanaan pemilihan umum dengan banyak partai, hal tersebut jarang terjadi pada negara-negara yang menganut sistem pemerintahan presidensil.

Memperhatikan pelaksanaan sistem pemerintahan presidensil Indonesia, kita dapat saja bandingkan dengan sistem pemerintahan presidensilnya Amerika Serikat dengan sistem pemerintahan presidensil murni (pure presidential system), dapat dilihat dalam ketentuan Undang-Undang Dasar Amerika Serikat sebagai berikut : Pasal II Ayat 1 Konstitusi Amerika Serikat menjelaskan bahwa “Kekuasaan eksekutif akan diberikan kepada seorang Presiden Amerika Serikat. Ia akan memanggu jabatannya dalam waktu empat tahun, dan bersama-sama dengan seorang Wakil Presiden, yang dipilih untuk jangka waktu yang sama”.

Dalam beberapa hal sistem pemerintahan presidensil Indonesia dan Amerika Serikat telah memiliki kesamaan misalnya ; 1) pemilihannya secara langsung oleh rayat; 2) memiliki masa pemerintahan yang tetap; 3) tidak bertangung jawab kepada parlemen; 4) tidak saling menjatuhkan. Akan tetapi terdapat hal yang berbeda antara lain : 1) pengusung calon presiden hanya terdapat 2 partai politik saja untuk Amerika Serikat, sementara terdapat banyak partai untuk Indonesia; 2)memiliki hak veto atas suatu undang-undang untuk Amerika Serikat dan tidak memiliki hak veto atas suatu undang-undang untuk Indonesia. 


\section{PENUTUP}

\section{KESIMPULAN}

1. Perubahan konstitusi adalah merupakan suatu mekanisme konstitusional, dan bukan disakralkan, seperti yang telah dilakukan dalam praktek-praktek ketatanegaraan di dunia seperti Amerika Serikat, Kanada, Indonesia dan beberapa negara eropah maupun asia lainnya.

2. Lembaga legislatif sebagai lembaga perwakilan rakyat (parlemen) yang memegang kedaulatan rakyat, dalam praktek-praktek ketatanegaraan secara umum dilakukan dengan sistem dua kamar (becameral system) dengan kedudukan antar lembaga parlemen tersebut memiliki kedudukan yang samasama kuat (strong becameral). Seperti yang dilakukan oleh negara Amerika Serikat dan negara-negara besar lainnya. Walaupun terdapat pula beberapa negara yang menganut parlemen dengan satu kamar (unicameral), seperti negara monarki absolute.

3. Lembaga yudikatif sebagai lembaga yang memegang kekuasaan kehakiman, dalam praktek-praktek ketatanegaraan secara umum dilakukan dengan sistem kekuasaan yang terpusat pada suatu lembaga negara dan sistem kekuasaan yang terbagi-bagi pada beberapa lembaga negara. Kekuasaan yang terpusat pada suatu lembaga negara dimaksudkan agar terciptanya suatu efisiensi dalam proses peradilan seperti yang dilakukan lembaga peradilan Amerika Serikat, sedangkan kekuasaan yang terbagi-bagi kepada beberapa lembaga negara dimaksudkan agar tercapainya kepastian dan rasa keadilan dalam proses peradilan, seperti yang dilakukan lembaga peradilan Indonesia.

4. Kekuasaan eksekutif sebagai pemegang kekuasaan pemerintahan dalam praktek ketatanegaraan dilakukan dengan sistem parlementer di mana kekuasaan parlemen lebih kuat dari pada pemerintah, seperti yang dilakukan pada negara Jepang atau Indonesia pada masa sebelum reformasi, sistem presidensil di mana kekuasaan parlemen memiliki kedudukan yang sama dengan pemeritah, seperti yang dilakukan pada negara Amerika Serikat dan Indonesia pasca reformasi dan system referendum yang mendudukan rakyat 
sebagai pembuat segala kebijakan dalam pemerintahan, seperti yang dilakukan oleh negara Swis dan beberapa negara Skandinavia.

5. Sebagaimana diuraikan diatas, maka dalam sejarah konstitusi Republik Indonesia, konstitusi telah mengalami perubahan maupun penggantian yang dilakukan oleh pemerintahan masa lalu sampai masa kini dengan berbagai pertimbangan kondisi sosial, politik maupun ekonomi yang sangat sulit untuk dihindarkan. Namun pada dasarnya Undang-Undang Dasar 1945 adalah merupakan konstitusi yang lentur (flexible) hal ini dikarenakan dalam ketentuan pasal 37 Undang-Undang Dasar 1945 naskah asli sebelum perubahan, maupun naskah sesudah perubahan tetap mengatur tentang tata cara bagaimana merubah Undang-Undang Dasar 1945.

\section{SARAN.}

1. Untuk menyempurnakan kekurangan-kekurangan yang berkaitan dengan sistem ketatanegaraan Indonesia, agar dilakukan amandemen yang kelima dan yang seterusnya.

2. Untuk menyempurnakan sistem kelembagaan parlemen (legislatf) Indonesia, seharusnya Indonesia menganut kepada becamiral sistem dengan strong becameral seperti Amerika Serikat dan beberapa negara besar lainnya.

3. Untuk menyempurnakan sistem kelembagaan kehakiman (yudikatif) dengan tetap menerapkan sistem kekuasaan yang terbagi-bagi, akan tetapi agar diberikan tambahan kewenangan yang sama kepada Komisi Yudisial seperti Mahkamah Agung dan Mahkamah Konstitusi, walaupun kewenangan tersebut tetap dalam kontek pengangkatan hakim agung dan pengawasan para hakim.

4. Untuk menyempurnakan sistem kelembagaan pemerintahan (eksekutif) dengan tetap mempertahankan sstem pemerintahan yang saat ini, namun diperbaiki pada proses pemilihan umum dengan memperketat parliamentary threshold (PTH) agar komposisi kekuatan politik di parlemen tidak terlalu banyak dan tidak efisies. 


\section{DAFTAR PUSTAKA}

\section{BUKU}

Dasril Radjab. Hukum Tata Negara Indonesia, Rineka Cipta Jakarta 2005

I Dewa Made Atmadja. Hukum Konstitusi, Problematika Konstitusi Indonesia Sesudah Perubahan UUD 1945, Setia Press Malang 2012

Jimly Assidiqy.Pengantar Ilmu Hukum Tata Negara. Raja Grafindo Persada. Jakarta 2009.

Jimly Asshidiqy,Menuju Negara Hukum Yang Demokratis, Sekeretariat Jenderal Makamah Konstitusi RI Jakarta 2008

Jimly Asshidiqy,Menuju Negara Hukum Yang Demokratis, Sekeretariat Jenderal Makamah Konstitusi RI Jakarta 2008

John M. Echols, Hassan Sadily, Kamus Iggris Indonesia, An-English-Indonesian Dictionary. Gramedia Jakarta, 2005

Muhammad Kusnardi, Harmaily Ibrahim, Pengantar Hukum Tata Negara Indonesia. Pusat Studi Hukum Tata Negara Indonesia. 1983. Hlm. 53

Moh. Mahfud MD. Perdebatan Hukum Tata Negara Pasca Amandemen Konstitusi. LP3ES Jakarta 2007

Ni'matul Huda, Hukum Tata Negara Indonesia, Raja Grafindo Persada Jakarta 2005

\section{PERATURAN PERUNDANG-UNDANGAN}

Undang-Undang Dasar 1945.

Undang-Undang Nomor : 48 Tahum 2009 Tentang Kekuasaan Kehakiman.

Undang-Undang Nomor : 24 Tahun 2003 Tentang Mahkamah Konstitusi.

Undang-Undang Nomor : 8 Tahun 2011 Tentang Perubahan Atas Undang-

Undang Nomor : 24 Tahun 2003 Tentang Mahkamah Konstitusi. 
Undang-Undang Nomor : 14 Tahun 1985 Tentang Mahkamah Agung.

Undang-Undang Nomor : 5 Tahun 2004 Tentang Perubahan Atas Undang-

Undang Nomor : 14 Tahun 1985 Tentang Mahkamah Agung.

Undang-Undang Nomor : 15 Tahun 2011 Tentang Susunan dan Kedudukan

MPR, DPR, DPD, dan DPRD.

Undang-Undang Nomor : 8 Tahun 2012 Tentang Pemilihan Umum Presiden.

\section{MAJALAH, JURNAL, DAN WEBSITE}

Naskah Akademik Perubahan Kelima Undang-Undang Dasar Negara Republik Indonesia Tahun 1945 Kelompok Dewan Perwakilan Daerah di MPR RI Tahun 2011

Naskah Akademik Perubahan Kelima Undang-Undang Dasar Negara Republik Indonesia Tahun 1945 Usul Perubahan Pasal Beserta Alasannya, Kelompok Dewan Perwakilan Daerah di MPR RI Tahun 2011.

www.wikipedia.com. 08/01/2014

www.judiciary.usa.com. 08/01/2014 